\title{
The Exploration and Practice in Innovative Personnel Training of Computer Science and Technology
}

\author{
${ }^{\mathrm{a}}$ Li Jian, ${ }^{\mathrm{b}}$ Zhou Yuan \\ ${ }^{a, b}$ Department of computer engineering and science Henan Institute of Engineering Zhengzhou Henan China
}

\begin{abstract}
In this paper, the author expounded on the investigation and understanding in the innovative ability of the contemporary college students, and introduced their practical experience and concrete measures in theoretical teaching, practice teaching, graduation design and technological innovation activities in the specialty of the Computer Science and Technology.
\end{abstract}

Index Terms: Computer Specialty; innovative talents; training; practice

In view of the features of Computer science, the social demand for the cultivation of innovative talents and the increasingly competitive talent market, how to make our students more innovative and capable, more competitive in the job-hunting tide should be taken seriously and conscientiously studied. In addition, the ability to develop creative thinking and innovation is currently an important part of quality education, and innovation is the concentrated expression of professional quality, therefore, to carry out innovative personnel training is the educational responsibilities that we must conduct.

(C) 2012 Published by MECS Publisher. Selection and/or peer review under responsibility of the International Conference on E-Business System and Education Technology

\section{Our Investigation and Understanding of the development in Creative psychology of Current college students}

Analyzing from the age structure, we find that the current college students are in the golden phase of their life which is most energetic, most developed in intelligence and most active in thinking. Compared with other youth groups, college students have more developing opportunities in their intellectual and innovative abilities, meanwhile, their sense and psychology in innovation has their own characteristics which will be shown during its development.

To understand the current tendency in the creativity of college students, we use the test questions designed by the American psychologist Eugene - Lou Desai-“Eugene creative aptitude test table”. The test is conducted among the students of grade one to grade three who have different majors in two colleges. We prepared a network test program, conducted the test through the network, which means the students answer the questionnaires on the internet, so that students could log in their answers without any interference.

Corresponding author:

E-mail address: ${ }^{\mathrm{a}}$ oklj@tom.com, ${ }^{\mathrm{b}}$ xuexiaoyoujian@126.com 
In the test, 916 valid questionnaires were received, of which 552 boys and 364 girls, the test information are as follows:

\subsection{The state of the participants in innovative training and invention}

Only one of the 916 participants had previously participated in innovation and creativity training, which is "Innovative thinking and Electronic Design". Only one student who produced a two-way burglar alarm participated in the small technological production activity. A student won a second price in Henan Province in CUMCM (China Undergraduate Mathematical Contest in Modeling). A student was awarded in the "Craft Contest”. There ate still other students who won awards in writing contest, etc.

\subsection{The basic data obtained from the test}

Seen from the test result, 50 testers of the 916 students have very strong creativity, 512 testers strong, 4 testers weak, 290 testers average and 60 with no creativity. Specific results summarized as follows in table 1:

TABLE I. Summary of creativity test scores

\begin{tabular}{|c|c|c|c|c|c|c|c|c|c|c|c|}
\hline $\begin{array}{c}\text { patam } \\
\text { Categof } \\
y\end{array}$ & $\begin{array}{c}\text { numb } \\
\text { ers }\end{array}$ & $\begin{array}{c}\text { Very } \\
\text { creati } \\
\text { ve }\end{array}$ & $\begin{array}{c}\text { Percenta } \\
\text { ge of } \\
\text { the total } \\
\text { number }\end{array}$ & $\begin{array}{c}\text { creati } \\
\text { ve }\end{array}$ & $\begin{array}{c}\text { Percent } \\
\text { age of } \\
\text { the total } \\
\text { number }\end{array}$ & $\begin{array}{c}\text { Weak } \\
\text { creati } \\
\text { ve }\end{array}$ & $\begin{array}{c}\text { Percent } \\
\text { age of } \\
\text { the total } \\
\text { number }\end{array}$ & $\begin{array}{c}\text { avera } \\
\text { ge }\end{array}$ & $\begin{array}{c}\text { Percent } \\
\text { age of } \\
\text { the total } \\
\text { number }\end{array}$ & $\begin{array}{c}\text { No } \\
\text { creati } \\
\text { ve }\end{array}$ & $\begin{array}{c}\text { Percent } \\
\text { age of } \\
\text { the total } \\
\text { number }\end{array}$ \\
\hline $\begin{array}{c}\text { bo } \\
\text { ys }\end{array}$ & 552 & 30 & $3.28 \%$ & 302 & $32.97 \%$ & 2 & $0.22 \%$ & 174 & $19.00 \%$ & 44 & $4.80 \%$ \\
\hline $\begin{array}{c}\text { girl } \\
\text { s }\end{array}$ & 364 & 20 & $2.18 \%$ & 210 & $22.93 \%$ & 2 & $0.22 \%$ & 116 & $12.66 \%$ & 16 & $1.75 \%$ \\
\hline $\begin{array}{c}\text { tot } \\
\text { al }\end{array}$ & 916 & 50 & $5.46 \%$ & 512 & $55.90 \%$ & 4 & $0.44 \%$ & 280 & $31.66 \%$ & 60 & $6.55 \%$ \\
\hline
\end{tabular}

\subsection{Analysis of the test result}

The data shows that, although the students did not participate in training on Innovation and creation, 61.36\% of the students have strong or very strong creativity, while only $6.55 \%$ of them have no creativity. Meanwhile, the data shows that boys and girls have no significant difference in their creativity. Thus, having a huge creative potential is an important feature of contemporary college students. However, in many aspects, the huge creative potential of the contemporary college students is not so prominent and significant as people expect. For the reason, we think: Students' creativity is in a phase of germination and awakening which demonstrates the following characteristics:

i. Quick thinking, but they can’t guide it with creative thinking.

ii. The students are highly imaginative, but their creative ability can’t be fully utilized ${ }^{1}$.

iii. Highly inspired, but they can’t use creative means to grasp the inspiration ${ }^{2}$.

iv. Eager to create, but they can’t support their creation with creative methods.

\section{Combined with professional training objectives, Creative talents are Cultivated in teaching}

After years of tireless exploration and practice, we defined a system of innovative personnel training in the major of computer, developed a complete implementation of the program. In recent years, we practiced it 
successfully in the teaching.

\subsection{Start from the reform of teaching, we lay a good foundation for the cultivation of creative talents}

According to the latest development of computer technology, considering the demand for IT talents, referring to the latest vocational skills training courses, we revised the original teaching schedule, adjusted the curriculum and teaching requirements, and added some courses which are conducive to cultivate students' creativity. At the same time, we strengthened the requirements of practice teaching to enable students to become active knowledge pursuers. We emphasize the cultivation of their creative problem-solving and exploration. We regard the training of creativity and research ability in teaching as an important teaching value, and as the highest standard in the classroom teaching impact assessment. We change the examination methods in the courses of Computer Introduction and Program Design. The examination is conducted through the operation on computers and flexible and diverse kinds of questions are utilized. In this way, it is probable to test how much knowledge the students grasp and test the students' ability in solving problems. It is possible to cultivate students' awareness of innovation and their capability in innovation.

\subsection{Strengthen the students' sense of scientific research and innovation in teaching}

We pay great attention to introducing the latest development and research results of concerning discipline into the teaching, promoting students to learn research information concerned on the frontier, to understand such research results, hoping to broaden the students' horizon in knowledge, to strengthen the students' sense of innovation. Some teachers also introduce appropriately some of their innovative research results to the students which can play the role of guide and model, easy to produce subtle but profound impact. This method not only can integrate concerning research with teaching content organically, but also enhance the students understanding about the content, stimulating the students' interest in research. This way can stimulate the students' desire to explore academic issues, which is welcomed by the students, and this way can function as a model to improve the students in analyzing and studying questions.

\subsection{Reform of teaching methods to stimulate students' interest in scientific research and innovation}

If the students are interested in research and innovation of the knowledge they have learned, they will have a strong thirst for knowledge, they will eagerly learn and study. If we want to fully mobilize and stimulate the students' interest in scientific research and innovation, teachers need to continuously improve and optimize the teaching methods. We often use the "problem" teaching model, practice model, "discussion" teaching model, and such flexible and diverse teaching methods, trying to teach students in accordance with their aptitude. For example, at the beginning of the "problem" teaching model, we tell the students the different understandings about the teaching content concerned and the focus of the debate. The students discuss this issue, trying to find out the way of solving the problem, in order to achieve the scientific resolution of the problem, which aims at training their ability in identifying, analyzing and solving problems. This problem is not only an introduction to teaching (the teaching model of problem-solving), but also the core of teaching (around the issue to expand and promote the teaching process). To solve the problem is the goal of teaching and it is the primary means of teaching (to solve the problem is the method of mastering knowledge, analyzing and solving problems), through which students' initial research and innovation capacity can be developed.

\subsection{Teach the students the basic way and strategy in innovation, train the students' innovative capability}

A good teacher, not only tells students knowledge, but tells them how to acquire knowledge3. Therefore, in our classroom teaching, attention is paid to teaching students the basic methods of scientific research and innovation, in order to cultivate their ability to solve new problems in their future work posts. In daily teaching, we pay more attention to arranging students some complicated projects, such as papers or designs. In instructing their works, we intentionally teach them some basic scientific and research methods, for example, 
how to select topics, how to collect and analyze materials, how to refine argument, how to arrange the layout and structure of papers, how to elaborate, how to modify and learn the written format and standard of papers, etc. Through basic training on scientific innovation, the teachers give the students necessary guidance and counseling, which will enable the students to master the methods and the ways of scientific and research innovation.

\section{Creative Ability training in Practice Teaching.}

Practice teaching is the main way to develop the students' creative capability, which is the most vivid and most lively place. However, traditional teaching philosophy and method obstructs its exertion of practice functions. The research and improvement in practice teaching, the introduction of research, design, integrated practice content, enhance the students' creativity and practical ability. In order to ensure that students get as much training in practical activities as possible, we conducted hard-working exploration and constructed the framework of the implementation.

\section{1 Increase the proportion of comprehensive experiments}

The main form of practice teaching is experimentation. Experiments can be divided into confirmatory experiments, design experiments and comprehensive experiments, of which confirmatory experiments and design experiments are intended to verify the important points in the theoretical teaching to help the students understanding thoroughly. Such experiments are focused on single questions and include single knowledge points, which greatly hinder the students' initiative and interest in learning. Comprehensive experiment is the integrated use of several knowledge points, project or system development is its main form, and it will synthesize a number of important knowledge points and validate them, which will construct a meaningful project.

\section{2 Provide space for outstanding students}

Uneven levels of students provide the students who have abundant learning power with more training space. When we design experimental task, we adopt multi-task design plan, and we establish a variety of assessment measures to encourage students to make excavation of their passion for learning and practice capabilities.

The multi-level and multi-task design plan explored by us has two main types. The first type is the multi-difficulty-level plan represented by Data Structure and Database courses. In this plan, the tasks of multiple degrees of difficulty are designed for the students to choose according to their capability. Completed in the correct context, the greater the degree of difficulty, the higher the test results are. The second category represented by Operating Systems is multiple juxtaposed ratios of difficulty for the students to choose. The more the number of completion, the higher the test results are. In practice, these two plans have achieved good results, which not only inspire the enthusiasm of the students and design capabilities, but also give the students the proper evaluation of the design. For those excellent course designs, it is allowed to apply for research credits. Certainly those who do not meet the requirements can't pass. After we standardized the practice procedure, the passing ratio of $100 \%$ has become history in the practice teaching for the last two years.

\section{3 Open Laboratory}

Experimental teaching is the essential link in the training of students' practical capability and creative capability. In order to maximize the use of laboratory resources, to better develop students' practical ability and innovation ability, to provide students with more independent learning and hands-on opportunity to practice, we put forward an open experiment teaching management mode based on extensive research. We developed the corresponding open experimental teaching management system to meet the needs of every department of the whole college. 


\section{Cultivating Creative Capability in Graduation Design}

Graduation project is an important part of teaching program, which is an important stage for the students to receive scientific education and engineering training, to improve the engineering practice ability. This is also an important way to cultivate students' good quality thinking and to give them comprehensive quality education. The graduation design is helpful to cultivate students' comprehensive use f multidisciplinary theory, knowledge and skills, to help them solve complex engineering practical problems. Meanwhile, it is of great use to cultivate students' correct design ideas and help them grasp modern design methods, to cultivate students' serious scientific attitude and rigorous working style, to cultivate students' thinking ability and strengthen their engineering awareness. And it is of vital importance to cultivate the students to be bold to practice, explore and innovate. All in all, through the educational function of graduation project, it is beneficial for the formation of students' intelligent structure and the training of students' comprehensive quality ${ }^{3}$.

In order to ensure and improve the training quality in the graduation project, we established specific implementation measures in several aspects, such as diversified graduation design approach, strict management and strengthened process management.

\section{Conclusion.}

The practice in the course of computer talent cultivation in the recent years proves that under the guidance of a set of relatively complete talent training system, it is practicable to gradually cultivate student's hands-on ability, innovative consciousness and ability, team cooperation ability and project research and development ability, thus better cultivating interdisciplinary talents characterized by strong innovative capability.

\section{References}

[1] Qian Guoying, “Innovation in Education and Cultivation of Practical Innovative Personnel”, The Press of Zhejiang University

[2] Li Qingshan, “Introduction of Thinking Innovation in College Students”, The Press of National Defense Industry

[3] Wang Hongzhong, Chen Xuexing, "The Cultivation of Innovative Capability”, The Press of Ocean University of China

[4] Yu Wei, “The Cultivation and Application of Innovative Capability”, The Press of Aviation Industry 